\title{
舌下部に発現した巨大な脂肪腫の一例
}

\author{
九州函科大学第 1 口腔外科学教室（指導：山田長敬教授） \\ 亀山嘉光・豊嶋健治・豊嶋昭治・木村卓生 \\ 九州荬科大学口腔病理学教室（指導：上野正康教授） \\ 村上俊 明・下川公一
}

（本論文の要旨は，昭和46年10月，第16回日本口腔外科学会総会において発表した）

\section{A Case of the Large Lipoma in the Sublingual Region}

By

Yoshimitsu Kameyama, Kenji Toyoshima, Shoji Toyoshima, Takuo Kimura

First Department of Oral Surgery (Director : Prof. Nagayoshi Yamada)

Toshiaki Murakami, Kouichi Shimokawa

Department of Oral Pathology (Director : Prof. Masayasu Ueno)

Kyushu Dental College; Kitakyushu, Japan

A lipoma is a soft tissue tumor consist of adipose tissue. However, although lipoma of the oral cavity are uncommon, the frequent location of the tumor are the cheek, the tongue, the lip and the floor of the mouth.

A case of large sublingual lipoma clinically suggestive of epidermoid cyst has been reported. The histo-pathologic feature seen in this tumor was lipoma.

\section{緒言}

脂肪腫は，脂肪組織よりなる腫湟で，全身の各所に発 生する良性腫煌である，口腔領域における発現は比較的 まれとされているが，煩部，舌，口唇および舌下部には 時折発生する.われわれは，今可，舌下部に発現した大 なる脂肪腫の一例を経験したので報䇤する．

\section{症例}

患者：江○○ヨ, 72才, 女性.

初診：昭和46年 4 月 1 日.

主訴：舌下部の腫脹.

家族歴および既往病歴：特記事項なし。

現病楚：昭和136年春頃，口腔底舌下部の軽度の腫脹と 異和感を自覚, その後, 腫脹は徐々に増大するも全く無 痛性渓経過し，わずかに置和感があるも何らの障害もな いため放置していた，昭和46年 3 月下旬, 義虍不適合を 主訴として某崡科を受邶したところ, 舌下部の腫脹を指 摘され，当院口腔外科外来を紹介されて来院した。

現症：
全身所見：体格中等度，栄養状態は可で，貧血傾向も 認められなかった。

局所所見: 顔貌は, 左右対称で顎下部の腫脹も認め ず，とくに記載すべき事項を認めなかった。

口腔内は, 開口障害もなく, 舌下部に小鶏卵大の腫脹 を認め, 粘膜色は正常で, 触知するに硬結はなく, 極め て柔軟な弾性に富む囊胞様物の存在を呈していた。また 压迫するも全く無痛性であった（写真 1 ）。

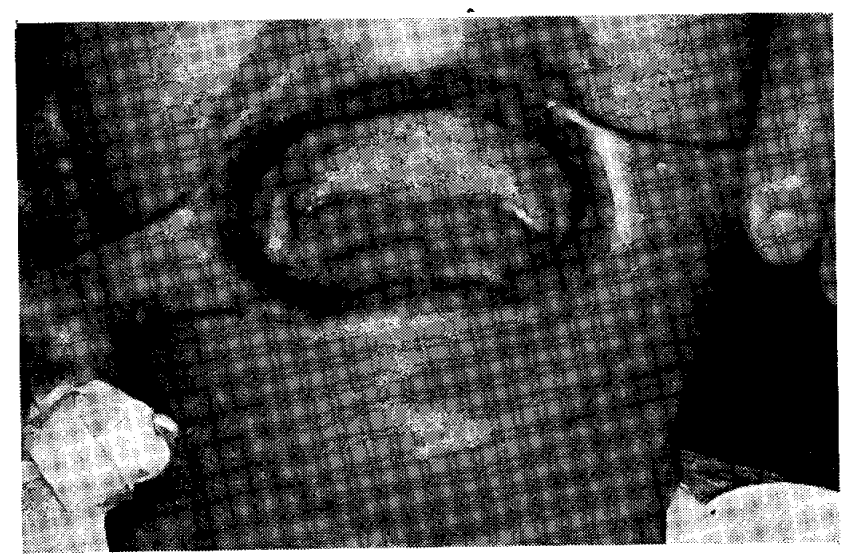

写真1口腔内所見 
臨床検査所見：

血液所見

赤血球数： $756 \times 10^{4} / \mathrm{mm}^{3}$

白血球数： $7 \times 10^{3} / \mathrm{mm}^{3}$

J自色素量： $87.5 \%$ (Sahli)

尿所見

尿 糖：(一)

尿蛋白：(一)

ウロビリノーダン：(土)

E. C. G. : within normal limits.

臨床㟝断：舌下部の脂肪腫の疑い.

処置および絽過：局所麻酔のもとに，口腔内より切 開，摘出を行なった。創腔は一部開放創としタンポン交 換を行なった。術後絽過良好で，13日目に退院し，現 在, 術後 4 年を経過するも再発の傾何を認めない.

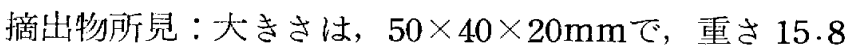
gr, 表面は平滑, 带黄色, 被囊性の腫瘤で 硬度は弾性 軟，割面は外層を海い結合性被膜に包まれ充実性の脂肪 組織であった(写真 2)．

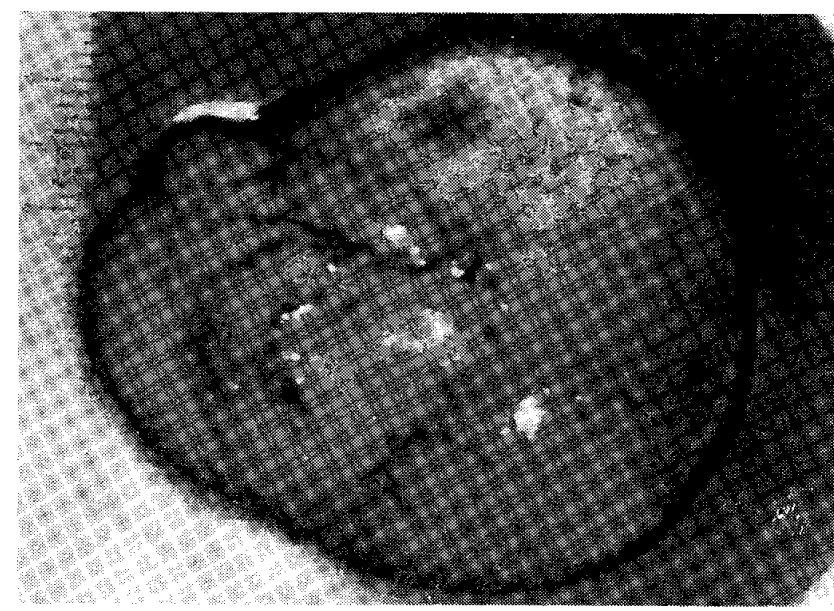

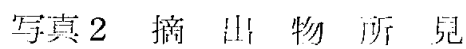

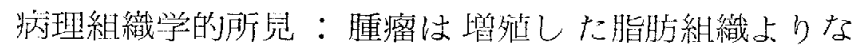
り，線維性結合組織の被膜を有し，队部は被膜と連続し た線維性結合組織の中澥によって分割され，分染構造を 呈していた，脂肪組織中の個々の脂肪紐胞は脂肪を多量 に掑取している成熟脂肪細胞が大部分を占めるが，とこ ろどころに大小不同が諗められる．乙れらの脂肪細胞は ズダンIII染色で橙黄色に好染した（写真 $3 〜 5)$ ）。

\section{考察}

口腔領域における脂肪腫の発現は比較的まれではある が，煩部，舌，口唇および舌下部などに見られる。

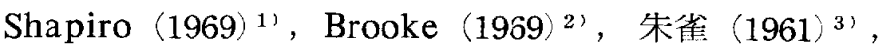

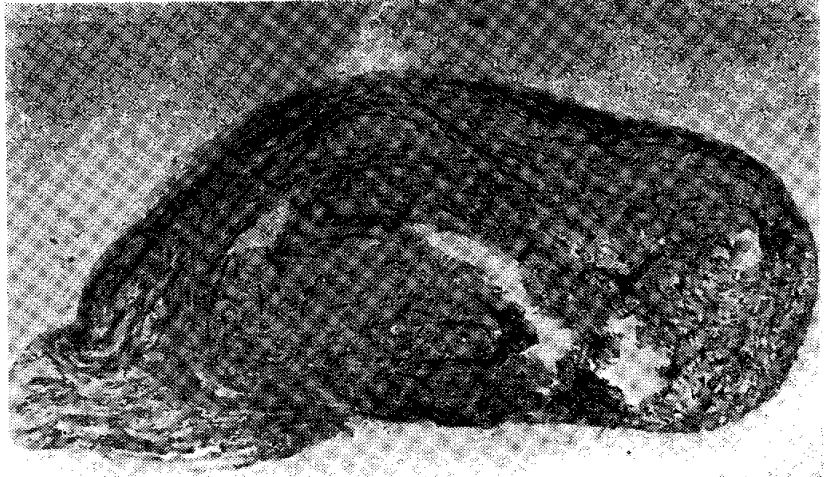

写真 3 摘出物全割西所罗

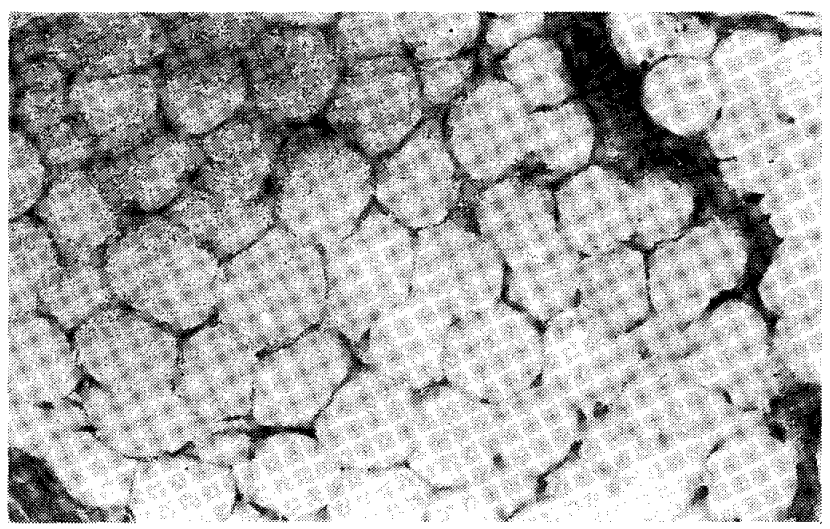

写真 4 病理所見（ズダン巩染色，弱払大）

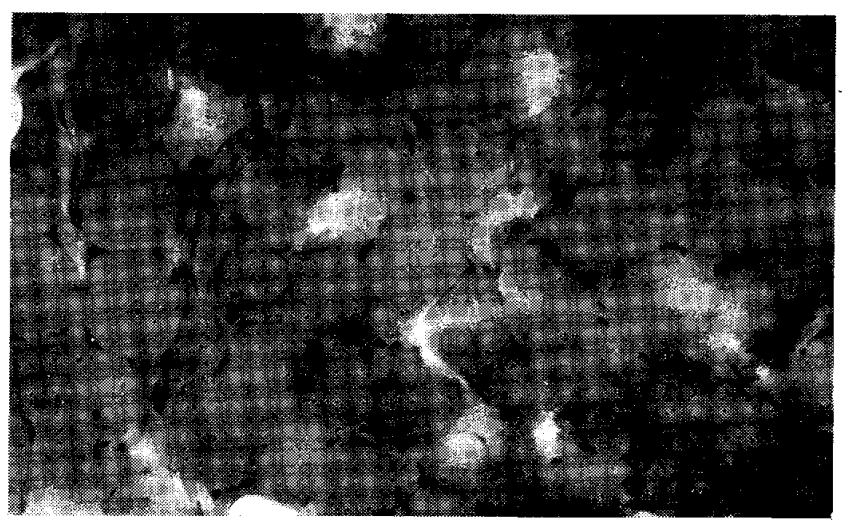

学真 5 昞理所見（ズダンIII染色，强拢大）

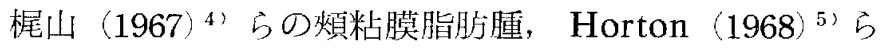
の舌脂肪腫, 大井 $(1963)^{6}$, 岡本 $(1963)^{7}$ ) らの口腔底 脂肪腫などの報告がある。

脂肪腫が口腔底に発生した場合, 類皮霊胞と非常にま ぎらわしい症状を星する，大井 $(1963)^{61}$ ，岡本 (1963) 7) らも類皮囊胞を疑って処置を行なった例を報告してい る。われわれが経験した症例は舌下部において，小鷄卵 大に腫脹を来し, 舌の举上を恋め, 極めて弾性軟にてあ たかも口腔底類皮囊胞を思わせる症状を呈した。しか し,患者が高年齢であることと硬度が極めて弾性に富み， 
柔らかいプワプワした感じであるととより舌下部の脂肪 腫を疑って摘出術を行なった。

舌下部における脂肪腫と類皮囊胞の鑑別において，患

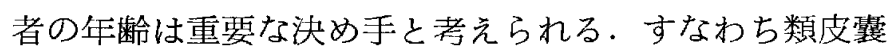
胞の場合は若年者に多く, 脂肪腫は成年以降に多いとさ れている．梶山 $(1967)^{4)}$ らの報告においても50代以後 の例が著しく多いとされている．さらには，遠藤（196 $\left.8^{8}\right)^{8)}$ が「その硬度と分葉観により」鑑別すべきだといっ ているように，その柔らかさが臨床的に診断の目安とな る. その他，舌下部に抢いて鑑別を要するものにガマ腫 があるが，乙れは穿刺を行なうととによって容易に鑑別 し得る。また Panders (1967) ${ }^{9}$ は，軟性線維腫，先天 性脂肪瘤なども鑑別が必要であり，多発性の柔らかい腫 脹などがある場合は，Recklinghausen's disease も考 えなければならないといっている。

脂肪腫の大きさについては, 過去に報告されたものの なかには，320 grもの大きなものがあるととを Horton

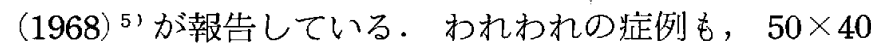
$\times 20 \mathrm{~mm}$ で重さ $15.8 \mathrm{gr}$ で過去の報告例に比べるとやや大 きい部類であるといえる。

病理組織学的には, 一般に, 単純性脂肪腫と線維性脂 肪腫に分類されているが，われわれの症例に扔いては， 線維性の中隔によって多数の脂肪細胞群に分割され, 不 規則な分葉構造を示し, 線維成分の少ない単純性脂肪腫 の像を呈していた．脂肪細胞は，大小不同のものは少な く成熟したものが多く，ズダンIII染色により脂肪滴が著 明に証明された。

\section{結論}

われわれは，72才，女性，舌下部類皮囊胞を思わせた 大なる脂肪腫の一症例を経験した。
稿を終るに臨み，終始御指導，御校閲を賜った山田長 敬教授ならびに上野正康教授に深謝致します。

\section{引用 文 献}

1. Shapiro, D. N. : Lipoma of the oral cavity, Oral Surgery, Oral Medicine and Oral Pathology 27 : 571-576, (1969).

2. Brook, R. I. : Traumatic pseudolipoma of the buccal mucosa, Oral Surgery, Oral Medicine and Oral Pathology 28:223-22 5 , (1969).

3. 朱雀直道・他：煩粘膜下に発生した脂肪腫の 2 症 例, 口科誌 $16: 499-504$, (1967).

4. 梶山 稔・他：脂肘腫の 2 例, 九州同会誌 $21: 34$ $-41, \quad$ (1967).

5. Horton, J. E. : Lipomas of the tongue, Oral Surgery, Oral Medicine and Oral Pathology $25: 914-917$, (1968).

6. 大井一正：口腔底に発現した巨大な脂肪腫の 1 例, 㠅科学報 $63: 362, \quad$ （1963）。

7. 岡本 治：臨木診断に扔いて皮様豪胞と詋診した脂 肪腫の 1 例, 歯科学報 $63: 749-750,(1963)$.

8. 遠藤至六郎：口腔外科学通論及手術学，458-475, 医学瑟房, 東京，(1963）。

9. Panders, A. K. : Oral lipoma, British Journal of Oral Surgery $5: 33-41$, (1967). 